\title{
PENERAPAN METODE MENDONGENG DALAM MENINGKATKAN AKTIVITAS BELAJAR PENDIDIKAN KEWARGANEGARAAN PADA SISWA KELAS III SDN. 101801 DELITUA KAB. DELISERDANG
}

\author{
Betty Girsang \\ Surel: bettygirsang@gmail.com
}

\begin{abstract}
ABSTRAK
Penelitian bertujuan untuk meningkatkan aktivitas belajar Pendidikan Kewarganegaraan pada Siswa Kelas III SDN. 101801 Delitua Kabupaten Deli Serdang dengan menggunakan metode mendongeng. Subjek penelitian berjumlah 32 siswa. Hasil penelitian menunjukkan adanya peningkatan pada perencanaan pembelajaran, pelaksanaan pembelajaran yang dilakukan oleh guru, dan aktivitas belajar siswa. Sedangkan respon siswa menyatakan tidak senang sudah tidak ada, yang menyatakan kurang senang menunjukkan penurunan, yang menyatakan senang mengalami kenaikan, dan yang menyatakan senang sekali mengalami kenaikan. Hasil evaluasi menunjukkan terdapat kenaikkan. Sedangkan yang belum tuntas belajar mengalami penurunan.
\end{abstract}

Kata Kunci : Aktivitas Belajar, Metode Mendongeng, PKN

\section{PENDAHULUAN}

Penyelenggaraan pendidikan merupakan tanggung jawab bersama antara pemerintah, masyarakat dan keluarga. Masing-masing memiliki peran yang sangat besar dalam rangka mewujudkan tujuan pendidikan. Keberhasilan penyelenggaraan pendidikan merupakan keberhasilan bersama. Tidak bisa salah satu pihak menyatakan dirinya sebagai yang paling berhasil dalam penyelenggaraan pendidikan.

Kesadaran orang tua, dan masyarakat dalam mendukung pelaksanaan kegiatan pendidikan sangat diperlukan. Setiap orang tua harus mampu memberikan motivasi yang besar kepada anak-anaknya untuk mengikuti kegiatan pembelajaran di sekolah. Sedangkan warga masyarakat juga harus dapat menciptakan kondisi lingkungan yang kondusif sehingga setiap anak selalu berusaha untuk dapat melakukan kegiatan belajar dengan aman dan nyaman.

SDN. $101801 \quad$ Delitua Kabupaten Deli Serdang merupakan salah satu sekolah dengan kondisi yang relatif terbatas. Kemampuan siswa, kepedulian orang tua, dan kondisi masyarakat, kurang maksimal dalam mendukung penyelenggaraan pendidikan di sekolah. Sehingga dalam proses penyelenggaraan pendidikan kurang dapat dilaksanakan secara maksimal.

Dalam pendidikan Kewarga Negaraan, kita mesti jeli mengikuti perkembangan pemerintahan, juga menjadi beban yang cukup berat bagi 
siswa untuk dapat berprestasi secara maksimal. Siswa kurang berminat dalam mengikuti pelajaran pendidikan Kewarganegaraan. Hasil yang diperoleh selalu saja mencapai rata-rata 6,5 sementara KKM yang sudah dfitentukan sekolah 6,8.

Pendidikan Kewarganegaraan bertujuan untuk mengembangkan potensi individu warga negara Indonesia sehingga memiliki wawasan, sikap, dan ketrampilan beragama yang memadai, yang memungkinkan untuk berpartisipasi secara cerdas dan bertanggung jawab dalam berbagai dimensi kehidupan bermasyarakat, berbangsa,beragama dan bernegara Indonesia.

Melihat kondisi nyata di sekolah dan memahami tujuan yang diharapkan dalam pembelajaran pendidikan Kewarganegaraan. perlu dilakukan upaya secara serius dan terus menerus agar kegiatan pembelajaran dapat berjalan dengan baik. Aktivitas belajar semakin meningkat dan prestasi belajar siswa juga semakin sesuai dengan yang diharapkan semua pihak.

Kondisi tersebut terutama terjadi pada siswa Kelas III SDN. 101801 Delitua Kabupaten Deli Serdang 2014/2015. Sehingga diperlukan usaha dari guru untuk dapat meningkatkan aktivitas belajar siswa dengan jalan memilih metode atau strategi pembelajaran yang tepat.

Untuk dapat meningkatkan aktivitas siswa dalam mengikuti kegiatan belajar mengajar, dan mendorong siswa selalu aktif dan kreatif dalam belajar, maka perlu strategi yang tepat. Strategi yang digunakan untuk mengatasi masalah tersebut adalah dengan metode mendongeng. Metode mendongeng merupakan strategi pembelajaran yang dirancang untuk memberikan terapi atas kemalasan siswa dalam mengikuti kegiatan belajar mengajar di kelas. Tehnik ini diberikan apabila dalam proses belajar mengajar ada siswa yang malas atau kurang bergairah dalam mengikuti pelajaran. Metode mendongeng diharapkan dapat memberikan situasi baru kepada siswa yang malas, sehingga berusaha dengan cepat untuk dapat menyesuaikan diri dengan temantemannya yang lain. Dampak metode mendongeng ini, siswa akan berusaha menyiapkan diri dengan baik dalam mengikuti kegiatan belajar mengajar di sekolah.

Berdasarkan uraian tersebut, peneliti menindaklanjuti dengan melakukan penelitian tindakan kelas dengan judul "Penerapan Metode Mendongeng Dalam Meningkatkan Aktivitas Belajar Pendidikan Kewarga Negaraan siswa Kelas III SDN. 101801 Delitua Kabupaten Deli Serdang TP. 2014/2015".

Tujuan utama dalam penelitian tindakan kelas ini adalah untuk meningkatkan aktivitas belajar Pendidikan Kewarga Negaraan siswa Kelas III SDN. 101801 Delitua 
Betty Girsang: Penerapan Metode Mendongeng ...

Kabupaten Deli Serdang melalui metode mendongeng.

\section{METODE PENELITIAN}

Penelitian tindakan kelas ini dilaksanakan di SDN. 101801 Delitua Kabupaten Deli Serdang pada Kelas III, dalam mata pelajaran Pendidikan Kewarganegaraan.

Penelitian tindakan kelas ini dilaksanakan dalam tahun pelajaran 2014/2015, semester genap, dari bulan Februari 2014 sampai dengan April 2015. Siswa Kelas III SDN 101801 Delitua Kabupaten Deli Serdang berjumlah 32 siswa. Tingkat kemampuan siswa berada pada tingkat menengah.

Dalam penelitian ini ada beberapa instrumen yang digunakan untuk menjaring data penelitian, antara lain: pedoman observasi, dokumen, dan catatan lapangan. Instrument penelitian disusun secara fleksibel dengan harapan agar segala bentuk permasalahan yang mungkin timbul dapat dieliminir dan dapat dicarikan solusinya dengan cepat dan tepat.

\section{HASIL DAN PEMBAHASAN}

Hasil penelitian dalam Penelitian Tindakan Kelas ini dijabarkan dalam tiga (3) kegiatan, yaitu (1) kegiatan pra tindakan, (2) kegiatan tindakan siklus I, dan (3) kegiatan tindakan siklus II.
1. Pengamatan Terhadap Kegiatan Guru

Berdasarkan hasil pengamatan kegiatan guru, maka dapat disusun tabel sebagai berikut:

Tabel 1. Rekapitulasi Hasil Observasi Kegiatan Guru Siklus I

\begin{tabular}{|c|c|c|c|}
\hline \multirow{2}{*}{ No } & \multirow{2}{*}{ Kegiatan } & \multicolumn{2}{|c|}{ Siklus I } \\
\cline { 3 - 4 } & & Jml & $\%$ \\
\hline 1 & $\begin{array}{c}\text { Perencanaan } \\
\text { Pembelajaran }\end{array}$ & 17 & 85 \\
\hline 2 & $\begin{array}{c}\text { Pelaksanaan } \\
\text { Pembelajaran }\end{array}$ & 19 & $\begin{array}{c}79,1 \\
7\end{array}$ \\
\hline
\end{tabular}

2. Pengamatan Terhadap Aktivitas Belajar Siswa

Kegiatan pengamatan

terhadap aktivitas siswa dilakukan oleh guru maupun observer/pengamat pada saat siswa melakukan mendongeng. Berdasarkan hasil pengamatan aktivitas belajar siswa, dapat dikemukakan sebagai berikut:

Tabel 2. Hasil Observasi Aktivitas Belajar Siswa Siklus I

\begin{tabular}{|c|l|c|c|c|c|}
\hline \multirow{2}{*}{ No } & \multicolumn{2}{|c|}{ Indikator } & \multicolumn{4}{|c|}{$\begin{array}{c}\text { Skala } \\
\text { Penilaian }\end{array}$} \\
\cline { 3 - 6 } & & 1 & 2 & 3 & 4 \\
\hline 1 & Kehadiran siswa & & & $\sqrt{ }$ & \\
\hline 2 & $\begin{array}{l}\text { Perhatian terhadap } \\
\text { materi pelajaran }\end{array}$ & & & $\sqrt{ }$ & \\
\hline 3 & $\begin{array}{l}\text { Semangat mengikuti } \\
\text { pembelajaran }\end{array}$ & & $\sqrt{ }$ & & \\
\hline 4 & $\begin{array}{l}\text { Persiapan yang } \\
\text { dilakukan sebelum } \\
\text { belajar mengajar }\end{array}$ & & $\sqrt{ }$ & & \\
\hline
\end{tabular}




\begin{tabular}{|c|l|c|c|c|c|}
\hline 5 & $\begin{array}{l}\text { Pertanyaan- } \\
\text { pertanyaan yang } \\
\text { disampaikan }\end{array}$ & & $\sqrt{ }$ & & \\
\hline 6 & $\begin{array}{l}\text { Tanggapan atau } \\
\text { jawaban atas } \\
\text { pertanyaan guru }\end{array}$ & & $\sqrt{ }$ & \\
\hline 7 & $\begin{array}{l}\text { Penyelesaian tugas- } \\
\text { tugas yang } \\
\text { diberikan }\end{array}$ & & $\sqrt{ }$ & \\
\hline & \multicolumn{2}{|c|}{ Jumlah } & \multicolumn{2}{|c|}{18} \\
\hline & \multicolumn{2}{|c|}{$64,29 \%$} \\
\hline
\end{tabular}

3. Kuesioner Respon Siswa Terhadap Kegiatan Belajar Mengajar

Berdasarkan rekapitulasi hasil kuesioner respon siswa terhadap kegiatan belajar mengajar pada siklus I, dapat diketahui prosentase respon siswa dalam pembelajaran sebagaimana dalam tabel berikut ini:

Tabel 3. Presentase Hasil Kuesioner Respon Siswa Terhadap Kegiatan Belajar Mengajar Pada Siklus I

\begin{tabular}{|c|l|c|c|}
\hline No & \multicolumn{1}{|c|}{ Keterangan } & Jumlah & $\%$ \\
\hline 1 & Tidak senang & 0 & 0 \\
\hline 2 & Kurang senang & 9 & 28,12 \\
\hline 3 & Senang & 18 & 52,63 \\
\hline 4 & Senang Sekali & 5 & 15,63 \\
\hline & Jumlah & 32 & 100 \\
\hline
\end{tabular}

4. Hasil Evaluasi

Berdasarkan hasil evaluasi pada siklus I, siswa yang sudah tuntas belajar ada 23 siswa $(71,88 \%)$, sedangkan yang belum tuntas belajar ada 9 siswa $(28,12 \%)$.

Pelaksanaan tindakan yang dilakukan pada siklus II terdiri dari tiga (3) kali pertemuan, yang masingmasing pertemuan menggunakan waktu 90 menit. Jadi dalam siklus II menggunakan waktu 270 menit.

1. Pengamatan Terhadap Kegiatan Guru

Berdasarkan hasil pengamatan kegiatan guru, maka dapat disusun tabel sebagai berikut:

Tabel 4. Rekapitulasi Hasil Observasi Kegiatan Guru Siklus II

\begin{tabular}{|c|l|c|c|}
\hline No & \multicolumn{1}{|c|}{ Kegiatan } & \multicolumn{2}{c|}{ Siklus II } \\
\cline { 3 - 4 } & & Jml & $\%$ \\
\hline 1 & $\begin{array}{l}\text { Perencanaan } \\
\text { Pembelajaran }\end{array}$ & 19 & 95 \\
\hline 2 & $\begin{array}{l}\text { Pelaksanaan } \\
\text { Pembelajaran }\end{array}$ & 21 & 87,5 \\
\hline
\end{tabular}

2. Pengamatan Terhadap Aktivitas Belajar Siswa

Kegiatan pengamatan terhadap aktivitas siswa dilakukan oleh guru maupun observer/pengamat pada saat siswa melakukan mendongeng.

Berdasarkan hasil pengamatan aktivitas belajar siswa, maka dapat dikemukakan sebagai berikut: 
Tabel 5. Hasil Observasi Aktivitas Belajar Siswa Siklus II

\begin{tabular}{|c|l|c|c|c|c|}
\hline \multirow{2}{*}{ No } & \multicolumn{1}{|c|}{ Indikator } & \multicolumn{4}{|c|}{ Skala Penilaian } \\
\hline & & 1 & 2 & 3 & 4 \\
\hline 1 & Kehadiran siswa & & & $\sqrt{ }$ & \\
\hline 2 & $\begin{array}{l}\text { Perhatian terhadap } \\
\text { materi pelajaran }\end{array}$ & & & & $\sqrt{ }$ \\
\hline 3 & $\begin{array}{l}\text { Semangat } \\
\text { mengikuti } \\
\text { pmbelajaran }\end{array}$ & & & $\sqrt{ }$ & \\
\hline 4 & $\begin{array}{l}\text { Persiapan yang } \\
\text { dilakukan sebelum } \\
\text { belajar mengajar }\end{array}$ & & & $\sqrt{ }$ & \\
\hline 5 & $\begin{array}{l}\text { Pertanyaan- } \\
\text { pertanyaan yang } \\
\text { disampaikan }\end{array}$ & & & $\sqrt{ }$ & \\
\hline 6 & $\begin{array}{l}\text { Tanggapan atau } \\
\text { jawaban } \\
\text { pertanyaan guru }\end{array}$ & & & $\sqrt{ }$ & \\
\hline 7 & $\begin{array}{l}\text { Penyelesaian } \\
\text { tugas-tugas yang } \\
\text { diberikan }\end{array}$ & & & & $\sqrt{|c|} 23$ \\
\hline & \multicolumn{2}{|c|}{ Jumlah } & & & \\
\hline & Prosentase & & & \\
\hline
\end{tabular}

3. Kuesioner Respon Siswa Terhadap Kegiatan Belajar Mengajar

Berdasarkan rekapitulasi hasil kuesioner respon siswa terhadap kegiatan belajar mengajar pada siklus II, dapat diketahui prosentase respon siswa dalam pembelajaran sebagaimana dalam tabel berikut ini:

Tabel 6. Presentase Hasil Kuesioner Respon Siswa Terhadap Kegiatan Belajar Mengajar Pada Siklus II

\begin{tabular}{|c|c|c|c|}
\hline No & Keterangan & Jumlah & $\%$ \\
\hline 1 & Tidak senang & 0 & 0 \\
\hline 2 & Kurang senang & 3 & 9,37 \\
\hline 3 & Senang & 21 & $\begin{array}{c}65,6 \\
3\end{array}$ \\
\hline 4 & Senang Sekali & 8 & 25 \\
\hline & Jumlah & 32 & 100 \\
\hline
\end{tabular}

4. Hasil Evaluasi

Berdasarkan hasil evaluasi pada siklus II (lihat lampiran 10), siswa yang sudah tuntas belajar ada 29 siswa (90,63\%), sedangkan yang belum tuntas belajar ada 3 siswa $(9,37 \%)$.

\section{Pembahasan Keseluruhan}

Berdasarkan hasil observasi, pengisian angket oleh siswa, dan hasil tes yang dilakukan pada pra tindakan, siklus I dan siklus II, maka dapat diuraikan sebagai berikut:

a. Kegiatan Guru

Berdasarkan kegiatan yang dilakukan guru pada siklus I dan siklus II, dapat diketahui sebagaimana dalam tabel berikut ini:

Tabel 7. Perbandingan Kegiatan Guru Siklus I dan Siklus II

\begin{tabular}{|l|l|c|c|c|c|}
\hline \multirow{2}{*}{ No } & \multirow{2}{*}{ Kegiatan } & \multicolumn{2}{|c|}{ Siklus I } & \multicolumn{2}{c|}{ Siklus II } \\
\cline { 3 - 6 } & Jml & $\%$ & Jml & $\%$ \\
\hline 1 & $\begin{array}{l}\text { Perencanaan } \\
\text { Pembelajaran }\end{array}$ & 17 & 85 & 19 & 95 \\
\hline 2 & $\begin{array}{l}\text { Pelaksanaan } \\
\text { Pembelajaran }\end{array}$ & 19 & 79,17 & 21 & 87,5 \\
\hline
\end{tabular}

Perencanaan pembelajaran yang dilakukan oleh guru ada peningkatan dari $85 \%$ menjadi $95 \%$. Jadi perencanaan pembelajaran yang dilakukan oleh guru sangat baik. Sedangkan pelaksanaan pembelajaran yang dilakukan oleh guru juga menga-lami pengingkatan dari $79,17 \%$ pada siklus I menjadi $87,5 \%$ 
pada siklus II. Jadi pelaksanaan pembelajaran yang dilakukan oleh guru juga mengalami peningkatan.

b. Kegiatan Siswa

Dalam penelitian tindakan kelas ini, kegiatan siswa dikelompokkan menjadi dua, yaitu (1) hasil observasi aktivitas belajar siswa, dan (2) hasil kuesioner respon siswa terhadap kegiatan belajar mengajar.

\section{1) Hasil Observasi Aktivitas Belajar Siswa \\ Berdasarkan hasil pengamatan} tentang hasil observasi aktivitas belajar siswa pada siklus I dan siklus II, maka dapat diketahui sebagaimana dalam tabel berikut ini:

Tabel 8. Perbandingan Hasil Observasi Aktivitas Belajar Siswa Pada Siklus I dan Siklus II

\begin{tabular}{|c|c|c|c|}
\hline No & Siklus & Jumlah & Prosentase \\
\hline 1 & Siklus I & 18 & 64,84 \\
\hline 2 & Siklus II & 23 & 82,14 \\
\hline
\end{tabular}

Aktivitas belajar siswa, berdasarkan tabel di atas dapat diuraikan bahwa rata-rata prosentase pada siklus I sebesar $64,84 \%$. Namun dalam siklus II, aktivitas belajar siswa mengalami peningkatan, yaitu menjadi $82,14 \%$. Jadi aktivitas belajar siswa sudah baik.
2) Respon Siswa Terhadap Kegiatan Belajar Mengajar

Berdasarkan hasil kuesioner respon siswa terhadap kegiatan belajar mengajar yang dilakukan pada siklus I dan siklus II, maka dapat diketahui sebagaimana dalam tabel berikut ini:

Tabel 4.11 Perbandingan Respon Siswa Pada Siklus I dan Siklus II

\begin{tabular}{|c|c|c|c|c|c|}
\hline \multirow{2}{*}{ No } & \multirow{2}{*}{ Kualifikasi } & \multicolumn{2}{|c|}{ Siklus I } & \multicolumn{2}{c|}{ Siklus II } \\
\cline { 3 - 6 } & Jml & \% & Jml & \% \\
\hline 1 & $\begin{array}{c}\text { Tidak } \\
\text { senang }\end{array}$ & 0 & 0 & 0 & 0 \\
\hline 2 & $\begin{array}{c}\text { Kurang } \\
\text { senang }\end{array}$ & 9 & 28,12 & 3 & 9,37 \\
\hline 3 & Senang & 18 & 56,25 & 21 & 65,63 \\
\hline 4 & $\begin{array}{c}\text { Sangat } \\
\text { senang }\end{array}$ & 5 & 15,63 & 8 & 25,00 \\
\hline & Jumlah & 32 & 100 & 32 & 100 \\
\hline
\end{tabular}

Hasil kuesioner respon siswa terhadap kegiatan belajar mengajar menunjukkan bahwa kualifikasi yang menyatakan tidak senang sudah tidak ada, baik pada siklus I maupun pada siklus II. Sedangkan yang menyatakan kualifikasi kurang senang menunjukkan penurunan dari 9 siswa $(28,12 \%)$ pada siklus I, menjadi 3 siswa $(9,37 \%)$ pada siklus II. Kualifikasi yang menyatakan senang mengalami kenaikan dari 18 siswa $(56,25 \%)$ pada siklus I, menjadi 21 siswa $(65,63 \%)$ pada siklus II. Kualifikasi yang menyatakan sangat senang mengalami kenaikan dari 5 siswa $(15,63 \%)$ pada siklus I, menjadi 8 siswa (25\%) pada siklus II. 


\section{a. Hasil Evaluasi}

Berdasarkan hasil evaluasi yang dilakukan pada pra tindakan, siklus I, dan siklus II, maka dapat diketahui sebagaimana dalam tabel berikut ini:

\section{Tabel 4.12 Perbandingan Hasil Evaluasi}

\begin{tabular}{|c|c|c|c|c|c|}
\hline No & \multirow{2}{*}{ Kegiatan } & \multicolumn{2}{|c|}{ Tuntas } & \multicolumn{2}{c|}{$\begin{array}{c}\text { Belum } \\
\text { Tuntas }\end{array}$} \\
\cline { 3 - 6 } & & Jml & $\%$ & Jml & $\%$ \\
\hline 1 & $\begin{array}{c}\text { Pra } \\
\text { Tindakan }\end{array}$ & 21 & 65,63 & 11 & 34,37 \\
\hline 2 & Siklus I & 23 & 71,88 & 9 & 28,12 \\
\hline 3 & Siklus II & 29 & 90,63 & 3 & 9,37 \\
\hline
\end{tabular}

Peningkatan kegiatan guru dan aktivitas belajar siswa juga berpengaruh terhadap hasil evaluasi. Hasil evaluasi menunjukkan terdapat kenaikkan yang tuntas belajar dari 21 siswa $(65,63 \%)$ pada pra tindakan menjadi 23 siswa $(71,88 \%)$ pada siklus I, dan menjadi 29 siswa $(90,63 \%)$ pada siklus II. Sedangkan yang belum tuntas belajar mengalami penurunan dari 11 siswa $(34,37 \%)$ pada pra tindakan menjadi 9 siswa $(28,12 \%)$ pada siklus I, dan menjadi 3 siswa $(9,37 \%)$ pada siklus II.

\section{b. Pembuktian Hipotesis Tindakan}

Berdasarkan hasil analisis penelitian sebagaimana dijelaskan di atas, maka hipotesis tindakan yang menyatakan bahwa metode mendongeng digunakan dalam pembelajaran mata pelajaran Pendidikan Kewarganegaraan, maka aktivitas belajar siswa Kelas III SDN. 101801 Delitua Kabupaten Deli Serdang akan meningkat", dapat diterima.

Selain peningkatan aktivitas belajar siswa, pelaksanaan metode mendongeng juga dapat meningkatkan prestasi belajar siswa.

\section{SIMPULAN}

Berdasarkan hasil analisis data dan pembahasan hasil penelitian dalam bab terdahulu dapat ditarik kesimpulan sebagai berikut:

1. Kegiatan Guru

Kegiatan pembelajaran yang dilakukan oleh guru dapat dirumuskan sebagai berikut: Perencanaan pembelajaran, ada peningkatan dari $85 \%$ pada siklus I menjadi $95 \%$ pada siklus II. Jadi perencanaan pembelajaran yang dilakukan oleh guru sangat baik. Sedangkan pelaksanaan pembelajaran yang dilakukan oleh guru juga mengalami pengingkatan dari $79,17 \%$ pada siklus I menjadi $87,50 \%$ pada siklus II. Jadi pelaksanaan pembelajaran yang dilakukan oleh guru juga sangat baik.

\section{Aktivitas Belajar Siswa}

Aktivitas belajar siswa mengalami peningkatan, pada siklus I sebesar 64,84\%, Sedangkan dalam siklus II menjadi 82,14\%. 
3. Respon Siswa Terhadap Kegiatan Belajar Mengajar

Respon siswa terhadap kegiatan belajar mengajar dapat diuraikan sebagai berikut :

a. Kualifikasi yang menyatakan tidak senang sudah tidak ada, baik pada siklus I maupun pada siklus II.

b. Sedangkan yang menyatakan kualifikasi kurang senang menunjukkan penurunan dari 9 siswa $(28,12 \%)$ pada siklus I, menjadi 3 siswa $(9,37 \%)$ pada siklus II.

c. Kualifikasi yang menyatakan senang mengalami kenaikan dari 18 siswa $(56,25 \%)$ pada siklus I, menjadi 21 siswa $(65,63 \%)$ pada siklus II.

d. Kualifikasi yang menyatakan senang sekali mengalami kenaikan dari 5 siswa $(15,63 \%)$ pada siklus I, menjadi 8 siswa (25\%) pada siklus II.

\section{Hasil Evaluasi}

Hasil evaluasi menunjukkan terdapat kenaikkan yang tuntas belajar dari 21 siswa $(65,63 \%)$ pada pra tindakan menjadi 23 siswa $(71,88$ $\%$ ) pada siklus I, dan menjadi 29 siswa $(90,63 \%)$ pada siklus II. Sedangkan yang belum tuntas belajar mengalami penurunan dari 11 siswa $(34,37 \%)$ pada pra tindakan menjadi 9 siswa $(28,12 \%)$ pada siklus I, dan menjadi 3 siswa $(9,37 \%)$ pada siklus II.

\section{DAFTAR RUJUKAN}

Arikunto, Suharsimi, dkk. 2006. Penelitian Tindakan Kelas. Jakarta: PT Bumi Aksara.

Departemen Pendidikan Nasional. 2005. Materi Pelatihan Terintegrasi Pendidikan Kewarganegaraan, Buku 2. Jakarta: Direktorat Pendidikan Lanjutan Pertama.

Hamalik, Oemar. 1992. Psikologi Belajar dan Mengajar. Bandung: Sinar Baru.
Ketetapan MPR RI No. IV/MPR/1999, Tentang GBHN. Surabaya: Penabur Ilmu.

Miarsa, $\quad 1995$. Peningkatan Mutu Pendidikan, Jurnal Teknologi Pembelajaran. Malang: IPTPI.

Moeslichatoen. 2004. Metode Pengajaran di Taman Kanakkanak. Jakarta: PT Asdi Mahasatya.

Mulyasa, E.. 2005. Menjadi Guru Profesional, Menciptakan Pembelajaran Kreatif dan Menyenangkan. Bandung: PT Remaja Rosdakarya Offset. 
Betty Girsang: Penerapan Metode Mendongeng ...

Nazir, Moh. 1988. Metode

Penelitian. Jakarta: Ghalia

Indonesia.

Saiful Rachman, Yoto, Syarif Suhartadi, Suparti. 2006. Penelitian Tindakan Kelas dan Penulisan Karya Ilmiah. Surabaya: SIC Bekerjasama Dengan Dinas $P$ dan $K$ Provinsi Jawa Timur.

Slameto. 1991. Proses Belajar Mengajar Dalam Sistem Kredit Semester (SKS). Jakarta: Bumi Aksara.

Soetomo. 1993. Dasar-dasar Interaksi Belajar Mengajar. Surabaya: Usaha Nasional.

Zaini, Hisyan, dkk. 2004. Strategi Pembelajaran Aktif. Yogyakarta: CTSD. 